\title{
A dual symbiosis shared by two mussel species, Bathymodiolus azoricus and Bathymodiolus puteoserpentis (Bivalvia: Mytilidae), from hydrothermal vents along the northern Mid-Atlantic Ridge
}

\author{
Sébastien Duperron ${ }^{1,3}$, Claudia Bergin ${ }^{1}$, Frank Zielinski ${ }^{1}$, Anna Blazejak ${ }^{1}$, Annelie Pernthaler ${ }^{1}$, Zoe P. \\ McKiness $^{2}{ }^{1}$, Eric DeChaine ${ }^{2}$, Colleen M. Cavanaugh ${ }^{2}$ and Nicole Dubilier ${ }^{1 *}$
}

\footnotetext{
${ }^{1}$ Max Planck Institute for Marine Microbiology, Celsiusstr. 1, D-28359 Bremen, Germany

${ }^{2}$ Harvard University, Department of Organismic and Evolutionary Biology, Cambridge, MA 02138, USA

${ }^{3}$ IFREMER Département Environnement Profond, Centre de Brest, B. P. 70, 29263 Plouzané, France

*: ndubilie@mpi-bremen.de
}

\begin{abstract}
:
Bathymodiolus azoricus and Bathymodiolus puteoserpentis are symbiont-bearing mussels that dominate hydrothermal vent sites along the northern Mid-Atlantic Ridge (MAR). Both species live in symbiosis with two physiologically and phylogenetically distinct Gammaproteobacteria: a sulfuroxidizing chemoautotroph and a methane-oxidizer. A detailed analysis of mussels collected from four MAR vent sites (Menez Gwen, Lucky Strike, Rainbow, and Logatchev) using comparative 16S rRNA sequence analysis and fluorescence in situ hybridization (FISH) showed that the two mussel species share highly similar to identical symbiont phylotypes. FISH observations of symbiont distribution and relative abundances showed no obvious differences between the two host species. In contrast, distinct differences in relative symbiont abundances were observed between mussels from different sites, indicating that vent chemistry may influence the relative abundance of thiotrophs and methanotrophs in these dual symbioses.
\end{abstract}

Keywords: endosymbiosis, 16S rRNA, sulfur oxidizer, methane oxidizer, fluorescence in situ hybridization (FISH). phylogeny, bacteria 


\section{Introduction}

Mussels of the subfamily Bathymodiolinae (family Mytilidae) inhabit hydrothermal vents and cold seeps around the world (von Cosel, 2002). Their adaptive success in such challenging environments that are largely devoid of photosynthetic primary production and subject to rapid changes in geochemical regimes is due to their symbiotic association with chemosynthetic bacteria within their gills (Fisher, 1990; Cavanaugh et al., 2005). Two phylogenetically and physiologically distinct types of Gammaproteobacteria occur as symbionts in bathymodioline mussels: small chemoautotrophic bacteria shown to oxidize sulfide in at least one species (Nelson et al., 1995), and methanotrophic bacteria with typical stacked internal membranes that use methane both as an electron and a carbon source (Cavanaugh et al., 1987; Fisher, 1993; Distel and Cavanaugh, 1994). Some bathymodioline mussels harbor only a thiotrophic or a methanotrophic symbiont, while others live in a dual symbiosis, with both types of bacteria co-occurring in the gill bacteriocytes (Dechaine and Cavanaugh, 2005). These symbioses enable their hosts to colonize sulfide and/or methane rich environments, in which the primary production of the symbionts ensures the nutrition of the host (Fisher et al., 1987; Fisher and Childress, 1992; Distel and Cavanaugh, 1994; DeChaine and Cavanaugh, 2005).

Two species of bathymodioline mussels occur along the northern Mid-Atlantic Ridge (MAR) which are morphologically and genetically well differentiated (Craddock et al., 1995; Maas et al., 1999). Bathymodiolus azoricus occurs at the northernmost sites (Menez Gwen, Lucky Strike, Rainbow), while B. puteoserpentis is found at the 2 vent sites closest to the equator (Snake Pit and Logatchev), with a hybrid zone where both species co-occur at Broken Spur (O'Mullan et al., 2001) (Fig. 1). These two mussel species harbor both thiotrophic and methanotrophic symbionts, based on transmission electron microscopy (TEM), and enzymatic and physiological assays (Cavanaugh et al., 1992; Fiala-Médioni et al, 2002). Studies using 16S rRNA sequence analysis and fluorescence in situ hybridization (FISH) confirmed the simultaneous presence of thiotrophic and methanotrophic phylotypes in gill cells of $B$. puteoserpentis from the Snake Pit site (Distel et al., 1995). The relative abundance of thiotrophs and methanotrophs, and stable carbon isotope signatures of symbiotic gill tissue can vary both between mussels from a single site, as well as between mussels from different vent sites, indicating that the symbiosis may respond flexibly to differences in vent chemistry (Trask and Van Dover, 1999; Colaco et al, 2002; FialaMédioni et al., 2002).

In the present study, our aim was to determine whether Bathymodiolus azoricus and B. puteoserpentis share the same symbiotic $16 \mathrm{~S}$ rRNA phylotypes. This was first shown by Won et al. (2003) for the thiotrophic symbiont in these 2 mussel species, but not investigated for the methanotrophic symbiont and not confirmed for either symbiont type with FISH. For this study, symbionts were examined in mussels collected from 4 vents along the northern MAR, B. azoricus from Menez Gwen, Lucky Strike, and Rainbow, and B. puteoserpentis from Logatchev. The 16S rRNA sequences from the mussel symbionts were compared to published symbiont sequences from B. azoricus collected at Rainbow (Won et al., 2003) and B. puteoserpentis from Snake Pit (Distel et al., 1995; Won et al., 2003). FISH was used to confirm that the obtained sequences originated from symbionts in the gills and to examine if there are differences in symbiont distribution and relative abundance between the 2 mussel species and between mussels from different vent sites. 


\section{Material and methods}

\section{Organisms and sampling sites}

Bathymodiolus azoricus and $B$. puteoserpentis were collected from 4 hydrothermal vent sites located on the northern Mid-Atlantic Ridge (Fig. 1). B. azoricus specimens were collected from 3 sites: Menez Gwen (3751' $\mathrm{N}, 31^{\circ} 31^{\prime} \mathrm{W}$, $850 \mathrm{~m}$ depth) using the ROV Victor during the 2001 ATOS cruise (Ifremer), and

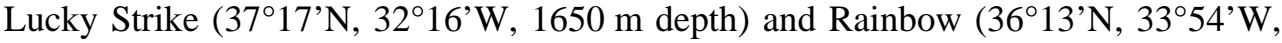
2350 m depth) using the DSV Alvin during the 2001 AT5-2 cruise (WHOI, 2001). $B$. puteoserpentis specimens were collected from the Logatchev site $\left(14^{\circ} 45.19^{\prime} \mathrm{N}\right.$, 4458.74'W, $3037 \mathrm{~m}$ depth) using the ROV Quest during the Meteor cruise Hydromar I, in February 2004.

Upon recovery, specimens were kept in insulated containers and chilled $\left(4^{\circ} \mathrm{C}\right)$ seawater until dissection. Symbiont-containing gill tissues from 2-4 individuals per site were dissected, with one part frozen immediately in liquid nitrogen and stored at $-20^{\circ} \mathrm{C}$ or $-80^{\circ} \mathrm{C}$ for DNA extraction and another part fixed for fluorescence in situ hybridization (FISH) (see below).

\section{DNA extraction and PCR amplification}

Total DNA was extracted and nearly full 16S rRNA gene sequences were amplified from frozen gill tissues of 3 individuals from Menez Gwen, 2 individuals each from Rainbow and Lucky Strike, and 4 individuals from Logatchev, using bacterial universal primers 8F and 1492R (Muyzer et al., 1995) and the same protocol and cycling conditions as previously described (Duperron et al., 2005). Four separate PCR reactions were run with 25 or 35 cycles each, and then pooled together prior to cloning.

\section{Cloning and sequencing}

For each specimen, the pooled PCR products were cloned and inserts of 15 to 100 positive clones were partially sequenced using primers $8 \mathrm{~F}$ or $519 \mathrm{~F}$, yielding sequences of $\sim 500$ bp. Partial sequences were aligned and compared with BioEdit (Hall, 1997-2001), and potential chimeras, detected by visual inspection of the alignments and using ChimeraCheck (Cole et al., 2003), were eliminated from further analyses. Representative clones were selected and their inserts fully sequenced in both directions (2 to 5 full sequences per individual and symbiont type). Methanotrophrelated sequences are registered at EMBL under accession numbers AM083950 to AM083967, thiotroph-related sequences under accession numbers AM083968 to AM083986.

\section{Sequence analysis}

Full sequences were aligned with a database containing over 30,000 sequences using ARB (Ludwig et al., 2004). Sequences from this study were aligned with symbiont sequences from the databases for MAR mussels and critically evaluated for nucleotide substitutions by assessment of position (e.g. stems vs. loops) and complementary base pairing in stems (EMBL accession numbers: Align_000930 (methanotrophs) and Align_000931 (thiotrophs)). Related sequences were compared to determine whether differences were unique or shared. Phylogenetic trees were calculated with maximum likelihood using Treefinder (Jobb, 2005), with an optimized General Time Reversible model. Bootstrap values were obtained from 200 replicates using similar parameters. 


\section{Probe design}

Specific oligonucleotide probes were designed for the two dominant 16S rRNA phylotypes obtained from Bathymodiolus azoricus and B. puteoserpentis using the PROBE_DESIGN tool of ARB, and their specificity tested against the ARB and Genbank databases. Both had at least 1 mismatch to all other sequences. Stringency and specificity of the Cy3- and Cy5-labeled probes (ThermoHybaid, Germany) was determined with the relevant reference symbiont or strain using a range of formamide concentrations (5 to 60\%). References for the thiotroph probe BMARt-193 (CGAAGGTCCTCCACTTTA) and methanotroph probe BMARm-845 (GCTCCGCCACTAAGCCTA) were a Bathymodiolus sp. symbiont from Gabon margin (2 mismatches; Duperron et al., 2005) and Xenorhabdus bovienii (1 mismatch; DSMZ strain 4766), respectively. Both probes hybridized specifically with their target at 30\% formamide. Eub 338 (Amann et al., 1990) and Non 338 (nonsense of Eub 338) (Wallner et al., 1993) were used as positive and negative controls. Four specific probes targeting the rare methanotroph-related phylotype found in a Menez Gwen $B$. azoricus specimen were designed: BazM2-845 (CAGGTTTAGTGGTGGAGC), BazM2-151 (ACGTGGTGAAAACCACGC), BazM2-233 (CTGCGTTAGATTAGCTGG) and BazM2-160 (AAACCACGCTAATACCGC). As this rare phylotype was not found using these probes (see Results and Discussion) their specificity was not further tested.

\section{Fluorescence in situ hybridization (FISH)}

Gill tissues of 2 individuals each from Rainbow and Lucky Strike, and of 4 individuals from Logatchev were fixed and prepared for FISH as described previously (Duperron et al., 2005). Sections were hybridized using $100 \mathrm{ng}$ of a given probe in 30 $\mu$ l hybridization buffer $(0.9 \mathrm{M} \mathrm{NaCl}, 0.02 \mathrm{M}$ Tris/HCl pH 8.0, $0.01 \%$ SDS, 30\% formamide) for $3 \mathrm{~h}$ at $46^{\circ} \mathrm{C}$ in pre-heated chambers saturated with hybridization buffer. After hybridization, sections were washed for $15 \mathrm{~min}$ at $48^{\circ} \mathrm{C}$ with buffer $(0.1$ $\mathrm{M} \mathrm{NaCl}, 0.02 \mathrm{M}$ Tris/HCl pH 8.0, 0.01 \% SDS, 5 mM EDTA), air dried, and mounted in a non-fluorescent medium (Vectashield, Vector). Sections were examined using a confocal laser-scanning microscope (Zeiss Axioplan 2, Germany). Distribution and relative abundance of bacterial endosymbionts within gill tissues was estimated qualitatively by eye with only those observations described in Results and Discussion that were consistent for all sections and all individuals examined. 


\section{Results and discussion}

\section{Symbiont diversity and phylogeny}

The 16S rRNA genes of bacterial symbionts from Bathymodiolus azoricus and $B$. puteoserpentis specimens collected at the MAR vent sites Menez Gwen, Lucky Strike, Rainbow, and Logatchev were sequenced and compared to published symbiont sequences from $B$. azoricus and $B$. puteoserpentis specimens collected at the MAR vent sites Rainbow and Snake Pit (Distel et al., 1995; Won et al., 2003) (Fig. 2). In both host species and at all 4 vent sites, all individuals contained 2 dominant bacterial phylotype groups in their 16S rRNA clone libraries. Within each phylotype group, sequences were highly similar with at least $99.7 \%$ sequence identity, while the difference between the 2 phylotypes groups was at least $11 \%$. Blast searches indicated one phylotype was more than $99 \%$ identical to the thiotrophic symbiont sequence of B. puteoserpentis from Snake Pit (Distel et al., 1995; Won et al., 2003) and B. azoricus from Rainbow (Won et al., 2003), and the other to the methanotrophic symbiont of B. puteoserpentis from Snake Pit (Distel et al., 1995). A third phylotype (AM083967) related to methanotrophic Bathymodiolus symbionts, but differing from the dominant methanotroph phylotype by $3 \%$, was found in only 2 clones (out of 50) from a single Menez Gwen B. azoricus individual.

Identity matrices, critical visual examination of the full alignment of the dominant MAR mussel symbiont sequences, and comparison to all bathymodioline symbiont sequences in the database, showed that out of $\sim 1500$ nucleotide positions, there were 0 - 3 nucleotide substitutions in each thiotrophic symbiont sequence. The majority of the nucleotide substitutions in the thiotrophic sequences were unique and not found in other sequences or individuals. Only 3 nucleotide substitutions in a single thiotrophic sequence from a Rainbow mussel (AM083974) were shared with a phylotype identified as rare in Rainbow mussels by Won et al. (2003) (Table 1). In the methanotrophic sequences, there were 0 - 7 nucleotide substitutions in each symbiont sequence, of which the majority were unique. Shared substitutions only occurred at 2 nucleotide positions, with a dominant Logatchev phylotype showing 1 substitution to mussels from all other sites and a less common Logatchev phylotype showing 2 substitutions to all other methanotrophic symbiont sequences (Table 1). These substitutions are not typical for $B$. puteoserpentis symbionts, because at Snake Pit, the symbionts of this mussel species are identical to the dominant phylotype (Distel et al. 1995)

Most of the unique nucleotide substitutions occurred in highly conserved regions of the 16S rRNA gene or resulted in miss-pairings of stem regions, indicating that these were caused by PCR or sequencing error. In contrast, the shared nucleotide substitutions shown in Table 1 are assumed to be real because they were observed in more than one individual. However, these 2-3 nucleotide differences were not host specific, that is only in B. azoricus or B. puteoserpentis symbionts, and for the thiotrophs also not site specific. They can therefore not be used for biogeography analyses or to discern relationships between the symbionts of these 2 mussel species. Finally and most importantly, such a minimal degree of sequence divergence, namely only $0.1-0.2 \%$ is not phylogenetically informative and would not allow the reconstruction of a robust tree. We thus conclude that Bathymodiolus azoricus and $B$. puteoserpentis individuals collected from vent sites along the MAR share highly similar to identical 16S rRNA phylotypes of the two dominant thiotroph- and methanotroph-related symbionts. 
One representative 16S rRNA sequence, with no unique nucleotide substitutions, was chosen for each of the two symbiont phylotypes and used for phylogenetic reconstruction (Fig. 2). The thiotrophic phylotype, together with the sequences previously published from B. azoricus and B. puteoserpentis (Distel et al., 1995; Won et al., 2003), falls within the larger group of mussel thiotrophic symbionts, and is related to a group of thiotropic symbionts from hydrothermal vent mussels including B. thermophilus (bootstrap value 76). The methanotrophic B. azoricus / B. puteoserpentis phylotype belongs to the monophyletic group of methanotrophic symbionts from other Bathymodiolus species, but its phylogenetic relationship to these symbionts is unresolved (bootstrap values below 60). The rare methanotrophic sequence from a single $B$. azoricus individual from Menez Gwen clearly falls within the monophyletic clade of Bathymodiolus methanotrophic symbionts (bootstrap value 100 ), but is only distantly related to the dominant B. azoricus / B. puteoserpentis methanotroph.

The 16S rRNA gene does not provide enough resolution to distinguish between bacterial species at the strain or sub-strain level. Instead, genes with higher substitution rates such as the internal transcribed spacer (ITS) of ribosomal operons are more useful for resolving the phylogeny of very closely related bacteria (Roth et al. 1998, Garcia-Martinez et al. 1999). Indeed, for the thiotrophic symbionts of $B$ azoricus and B. puteoserpentis, Won et al. (2003) and DeChaine et al. (submitted) showed that the ITS differs within and between host specimens collected from the same MAR vent site as well as from different MAR vent sites. This indicates that MAR mussels harbor multiple strains of thiotrophic symbionts and unpublished data by S. Hallam (cited in Won et al. 2003) suggests a similar heterogeneous mixture of methanotrophic symbionts in MAR mussels.

\section{Distribution and relative abundance of thiotrophs and methanotrophs}

Symbiont specific probes designed to target the dominant thiotrophic and methanotrophic 16S rRNA phylotype hybridized to their respective bacterial targets in the gills of Bathymodiolus azoricus and B. puteoserpentis (Fig. 3A-C). Both symbionts were detected in the apical part of the gill bacteriocytes, while the basal region and other parts of the gills including the ciliated ends of the filaments showed no signal. The rare methanotroph-related phylotype, found in the clone library from a single Menez Gwen individual, was not detected with FISH in Lucky Strike and Rainbow mussels, despite the design of 4 probes specific to this sequence. Unfortunately, no mussels from Menez Gwen were fixed for FISH analyses so that it remains unclear if this phylotype originated from a gill symbiont that only occurs in Menez Gwen mussels.

The distribution of the symbionts in the gill bacteriocytes was similar in individuals from the same site, but differed between sites. In Bathymodiolus azoricus from Rainbow (Fig. 3B), thiotrophs occurred in the apical region exposed to the mantle fluid and methanotrophs were more basal within the bacteriocytes. Thiotrophic and methanotrophic symbionts were more evenly distributed within bacteriocytes of B. azoricus from Lucky Strike (Fig. 3A) and B. puteoserpentis from Logatchev (Fig. 3C). As with the distribution of the 2 symbionts, the relative abundance of the methantrophs and thiotrophs was similar between mussels from the same site, but differed between vent sites. Methanotrophs were more abundant than thiotrophs in $B$. azoricus from Rainbow (Fig. 3B). In contrast, B. azoricus from Lucky Strike had more thiotrophs than methanotrophs (Fig. 3A), resembling B. puteoserpentis from Snake Pit (Distel et al., 1995). The ratio of methanotrophs to chemoautotrophs in $B$. 
puteoserpentis from Logatchev (Fig. 3C) was intermediate between the two $B$. azoricus described above, but specimens of this population had more methanotrophs than the previously described B. puteoserpentis from Snake Pit (Distel et al., 1995).

Symbiont distribution and relative abundance are clearly not host specific, as in both $B$. azoricus and $B$. puteoserpentis intraspecific differences were as distinct as those between the 2 species. A comparison of symbiont distribution and relative abundance to sulfide and methane concentrations in end-member fluids at the MAR vent sites is shown in Table 2. Symbionts were distributed evenly throughout the bacteriocytes at all sites except Rainbow, where methanotrophs were located in the basal and thiotrophs in the apical region of the gill cells. This distribution pattern was first observed in mussels from cold seeps on the Gabon continental margin and was hypothesized to reflect the high ratio of methane over sulfide in the seep environment (Duperron et al. 2005). Thiotrophs were assumed to be more dependent on being close to the mantle fluids because of the low sulfide concentrations in the environment while methanotrophs were assumed to be able to inhabit the basal region because diffusive loss of methane through the bacteriocytes could be compensated for by the higher methane concentrations. At Rainbow, sulfide and methane concentrations were similar in end-member fluids, making the hypothesis used to explain the uneven distribution of the symbionts in the Gabon seep mussels unlikely for the Rainbow mussels. However, single measurements taken at one point and time may not reflect average concentrations over longer times.

The Rainbow site was also the only one at which methanotrophs were more abundant than thiotrophs, corresponding well with methane concentrations in endmember fluids, which were higher at Rainbow than at other vent sites (Table 2). Analogously, at the 2 sites with the highest sulfide concentrations and sulfide over methane ratios, Lucky Strike and Snake Pit, thiotrophs were more abundant than methanotrophs. At the Lucky Strike site, the higher abundance of thiotrophs was also observed in earlier studies (Trask and van Dover, 1999; Fiala-Médioni et al., 2002) showing that the dominance of thiotrophic symbionts in the gills of these mussels has remained stable over time.

In summary, it appears as if vent chemistry affects the relative abundance of thiotrophs and methanotrophs, as suggested in earlier studies using transmission electron microscopy and stable isotope analysis (Trask and van Dover, 1999; Colaço et al., 2002; Fiala-Médioni et al., 2002). In contrast, no clear effect of sulfide and methane concentrations on symbiont distribution was observed in this study. However, the relative concentrations of sulfide and methane in end-member fluids may not be representative of their ratios in diffuse fluids that deliver these energy sources to the mussels. For future studies, time series measurements of gradients in vent fluids taken at the mussel collection sites should be combined with quantitative studies of relative symbiont abundance, for example using slot blot hybridization with thiotroph- and methanotroph-specific probes. The northern MAR vent sites, with their distinct differences in vent chemistry, yet highly similar to identical Bathymodiolus symbiont phylotypes provide an ideal study site for gaining a better understanding of how gradients in energy sources at hydrothermal vents influence the nutritional response of mussels with dual symbioses. 
Acknowledgments

We thank the captains and crew, ROV pilots, and chief scientists of the cruises of the ATOS, AT5-2 and Hydromar I cruises for their support and assistance in sample collection. Paul Dando is gratefully acknowledged for providing specimens from Menez Gwen. This research has been supported by grants from the German Research Foundation (DU 419/1-1 in the Priority Program 1144 RIDGE), the Max Planck Society, and the National Science Foundation (Biological Oceanography), and by the International Max Planck Research School of Marine Microbiology Ph.D. program (S.D. and F.Z.), Ifremer (S.D.), an NIH Genetics Training grant (Z.P.M), an NSF Postdoctoral Fellowship in Microbial Biology (DBI-0400591; E.G.D), and a HanseWissenschaftskolleg Fellowship (C.M.C), which we gratefully acknowledge. 
Amann, R., Binder, B.J., Olson, R.J., Chisholm, S.W., Devereux, R., and Stahl, D.A. (1990) Combination of 16S rRNA-targeted oligonucleotide probes with flow cytometry for analysing mixed microbial populations. Appl. Env. Microbiol. 56: 1919-1925.

Cavanaugh, C.M., Wirsen, C.O., and Jannash, H.W. (1992) Evidence for methylotrophic symbionts in a hydrothermal vent mussel (Bivalvia: Mytilidae) from the Mid-Atlantic Ridge. Appl. Env. Microbiol. 58: 3799-3803.

Cavanaugh, C.M., McKiness, Z. P., Newton, I. L. G. and Stewart, F.J. (2005) Marine chemosynthetic symbioses. In The Prokaryotes: an evolving electronic resource for the microbiological community. Dworkin, M.et.al. (eds). Springer-Verlag, New York.

Cavanaugh, C.M., Levering, P.R., Maki, J.S., Mitchell, R., and Lidstrom, M.E. (1987) Symbiosis of methylotrophic bacteria and deep-sea mussels. Nature 325: 346347.

Colaco, A., Dehairs, F., Desbruyères, D., Le Bris, N., and Sarradin, P.M. (2002) $\delta^{13} \mathrm{C}$ signature of hydrothermal mussels is related with the end-member fluid concentration of $\mathrm{H}_{2} \mathrm{~S}$ and $\mathrm{CH}_{4}$ at the Mid-Atlantic Ridge hydrothermal vent fields. Cah. Biol. Mar. 43: 259-262.

Cole, J.R., Chai, B., Marsh, T.L., Farris, R.J., Wang, Q., Kulam, S.A. et al. (2003) The Ribosomal Database Project (RDP-II): previewing a new autoaligner that allows regular updates and the new prokaryotic taxonomy. Nucl. Acids Res. 31: 442-443.

Craddock, C., Hoeh, W.R., Gustafson, R.G., Lutz, R.A., Hashimoto, J., and Vrijenhoek, R.J. (1995) Evolutionary relationships among deep-sea mytilids (Bivalvia: Mytilidae) from hydrothermal vents and cold water methane/sulfide seeps. Mar. Biol. 121: 477 - 485.

DeChaine, E.G., and Cavanaugh, C.M. (2005) Symbioses of methanotrophs and deepsea mussels (Mytilidae: Bathymodiolinae). In Molecular Basis of Symbiosis. Overmann, J. (ed): Springer-Verlag, New York. In press.

Desbruyères, D., Almeida, A., Biscoito, M., Comtet, T., Khripounoff, A. Le Bris, N., Sarradin, P.M., and Segonzac, M. (2000) A review of the distribution of hydrothermal vent communities along the northern Mid-Atlantic Ridge: dispersal vs. environmental controls. Hydrobiologia 440: 201-216.

Distel, D.L., and Cavanaugh, C.M. (1994) Independent phylogenetic origins of methanotrophic and chemoautotrophic bacterial endosymbioses in marine bivalves. J. Bacteriol. 176: 1932-1938.

Distel, D.L., Lee, H.K.W., and Cavanaugh, C.M. (1995) Intracellular coexistence of methano- and thioautotrophic bacteria in a hydrothermal vent mussel. Proc. Natl. Acad. Sci. USA 92: 9598-9602.

Douville, E., Charlou, J. L., Oeklers, H., Bienvenu, P., Jove Colon, C. F., Donval, J. P., Fouquet, Y., Prieur, D., Appriou, P. (2002) The Rainbow vent fluids (36 $\left.14^{\circ} \mathrm{N}, \mathrm{MAR}\right)$ : the influence of ultramafic rocks and phase separation on trace metal content in Mid-Atlantic Ridge hydrothermal fluids. Chem. Geol. 184: 37-48.

Duperron, S., Nadalig, T., Caprais, J.C., Sibuet, M., Fiala-Médioni, A., Amann, R., and Dubilier, N. Dual symbiosis in a Bathymodiolus mussel from a methane seep on the Gabon continental margin (South East Atlantic): 16S rRNA phylogeny and distribution of the symbionts in gills. Appl. Env. Microbiol. 71: 1694-1700. 
Fiala-Médioni, A., McKiness, Z.P., Dando, P., Boulegue, J., Mariotti, A., AlayseDanet, A.M. et al. (2002) Ultrastructural, biochemical, and immunological characterisation of two populations of the mytilid mussel Bathymodiolus azoricus from the Mid Atlantic Ridge: evidence for a dual symbiosis. Mar. Biol. 141: 1035-1043.

Fisher, C.R. (1990) Chemoautotrophic and methanotrophic symbioses in marine invertebrates. Rev. Aquat. Sci. 2: 399-613.

Fisher, C.R. (1993) Oxidation of methane by deep-sea mytilids in the Gulf of Mexico in Biochemistry of global change: radiative gases. Chapman \& Hull.

Fisher, C.R., and Childress, J.J. (1992) Organic carbon transfer from methanotrophic symbionts to the host hydrocarbon-seep mussel. Symbiosis 12: 221-235.

Fisher, C.R., Childress, J.J., Oremland, R.S., and Bidigare, R.R. (1987) The importance of methane and thiosulphate in the metabolism of the bacterial symbionts of two deep-sea mussels. Mar. Biol. 96: 59-71.

Garcia-Martinez, J., Acinas, S.G., Anton, A.I., and Rodriguez-Valera, F. (1999) Use of the 16S-23S ribosomal genes spacer region in studies of prokaryotic diversity. J. Microbiol. Methods. 36(1-2): 55-64.

Hall, T. (1997-2001) BioEdit. www.mbio.ncsu.edu/BioEdit/bioedit.html

Jobb, G. (2005) TREEFINDER version June 2005. Munich, Germany. Distributed by the author at www.treefinder.de.

Ludwig, W., Strunk, O., Westram, R., Richter, L., Meier, H., Yadhukumar et al. (2004) ARB: a software environment for sequence data. Nucl. Acids Res. 32: 1363-1371.

Maas, P.A.Y., O'Mullan, G.D., Lutz, R.A., and Vrijenhoek, R.C. (1999) Genetic and morphometric characterization of mussels (Bivalvia: Mytilidae) from MidAtlantic hydrothermal vents. Biol. Bull. 196: 265-272.

Muyzer, G., Teske, A., Wirsen, C.O., and Jannash, H.W. (1995) Phylogenetic relationships of Thiomicrospira species and their identification in deep-sea hydrothermal vent samples by denaturing gradient gel electrophoresis of $16 \mathrm{~S}$ rDNA fragments. Arch. Microbiol. 164: 165-172.

Nelson, D.C., Hagen, K.D., and Edwards, D.B. (1995) The gill symbiont of the hydrothermal vent mussel Bathymodiolus thermophilus is a psychrophilic, chemoautotrophic, sulfur bacterium. Mar. Biol. 121: 487-495.

O'Mullan, G.D., Maas, P.A.Y., Lutz, R.A., and Vrijenhoek, R.C. (2001) A hybrid zone between hydrothermal vent mussels (Bivalvia: Mytilidae) from the MidAtlantic Ridge. Mol. Ecol. 10: 2819-2831.

Roth, A., Fisher, M., Hamid, M.E., Michalke, S. Ludwig, W., and Mauch, H. (1998) Differentiation of phylogenetically related slowly growing mycobacteria based on 16S-23S rRNA gene internal transcribed spacer sequences. J. Clin. Microbiol. 36(1): 139-147.

Trask, J.L., and Van Dover, C.L. (1999) Site-specific and ontogenetic variations in nutrition of mussels (Bathymodiolus sp.) from the Lucky Strike hydrothermal vent field, Mid-Atlantic Ridge. Limnol. Oceanogr. 44: 334-343.

Von Cosel, R. (2002) A new species of bathymodioline mussel (Mollusca, Bivalvia, Mytilidae) from Mauritania (West Africa), with comments on the genus Bathymodiolus Kenk \& Wilson, 1985. Zoosystema 24: 259 - 271.

Wallner, G., Amann, R., and Beisker, W. (1993) Optimizing fluorescent in situhybridization with rRNA-targeted oligonucleotide probes for flow cytometric identification of microorganisms. Cytometry 14: 136-143. 
Won, Y.J., Hallam, S.J., O'Mullan, D., Pan, I.L., Buck, K.R., and Vrijenhoek, R.C. (2003) Environmental acquisition of thiotrophic endosymbionts by deep-sea mussels of the genus Bathymodiolus. Appl. Env. Microbiol. 69: 6785-6792. 


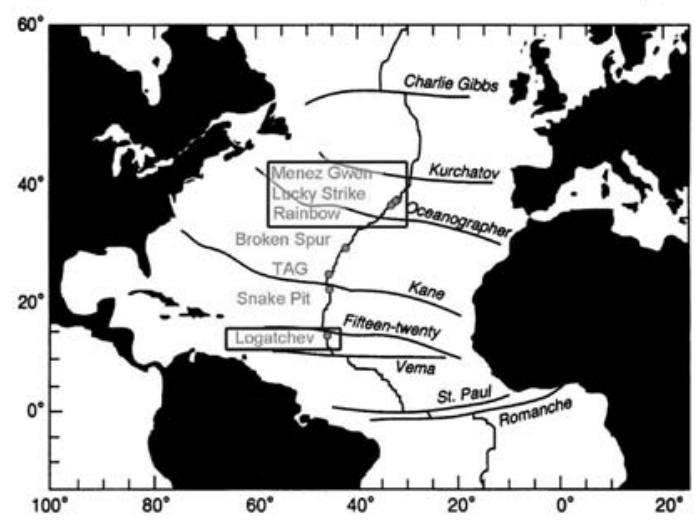

Fig.1: Hydrothermal vent sites on the northern MAR. Sites where mussels were collected for this study are framed. B. azoricus is found at Menez Gwen, Lucky Strike, and Rainbow, B. puteoserpentis at Snake Pit and Logatchev, and both species co-occur at Broken Spur (no mussels occur at TAG). 


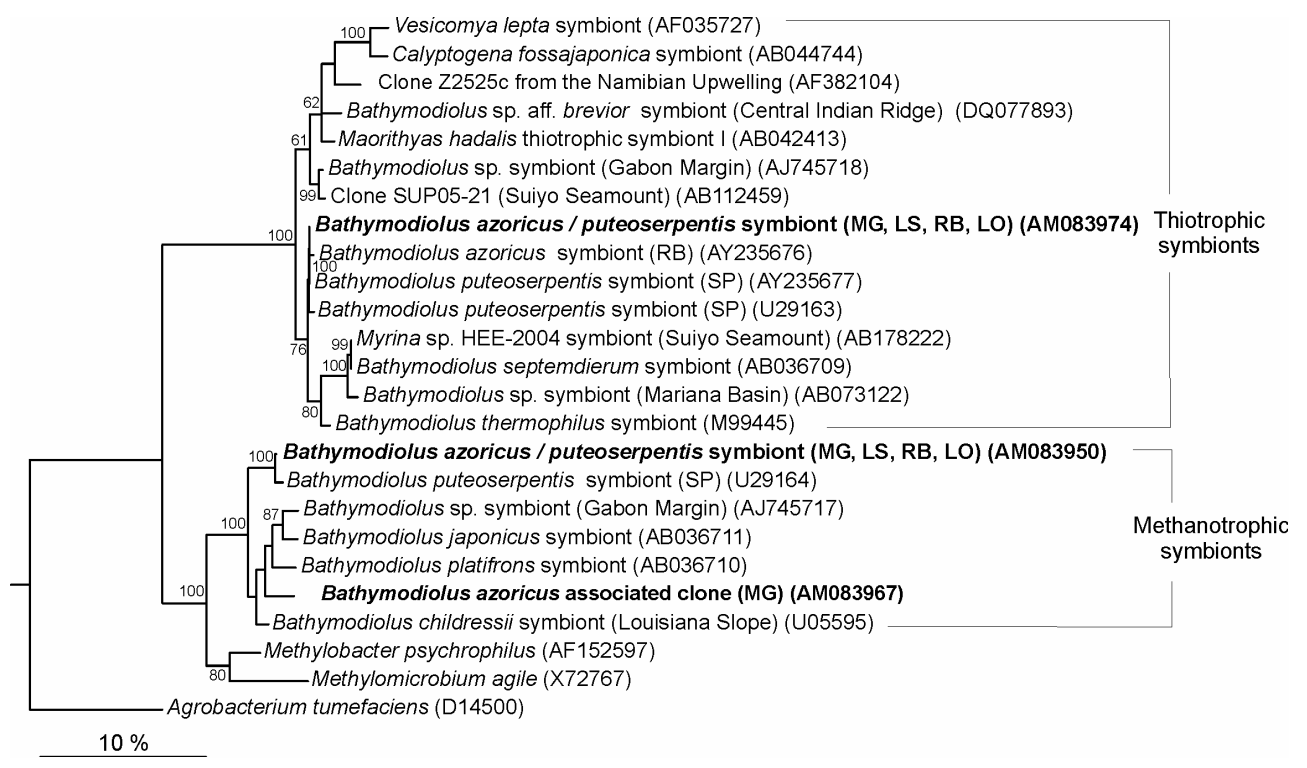

Fig. 2: Maximum likelihood tree based on 16S rRNA sequences from the thiotrophic and methanotrophic endosymbionts of bathymodioline mussels from the northern Mid-Atlantic Ridge (highlighted in bold) within the $\gamma$-Proteobacteria. Agrobacterium tumefaciens ( $\alpha$-proteobacteria) is included as an outgroup; $1309 \mathrm{nt}$ positions were used; $\mathrm{L}=-5906$. Bootstrap percentages obtained from $200 \mathrm{ML}$ replicates (values $>60$ shown). Scale bar represents $10 \%$ estimated nucleotide substitution. 

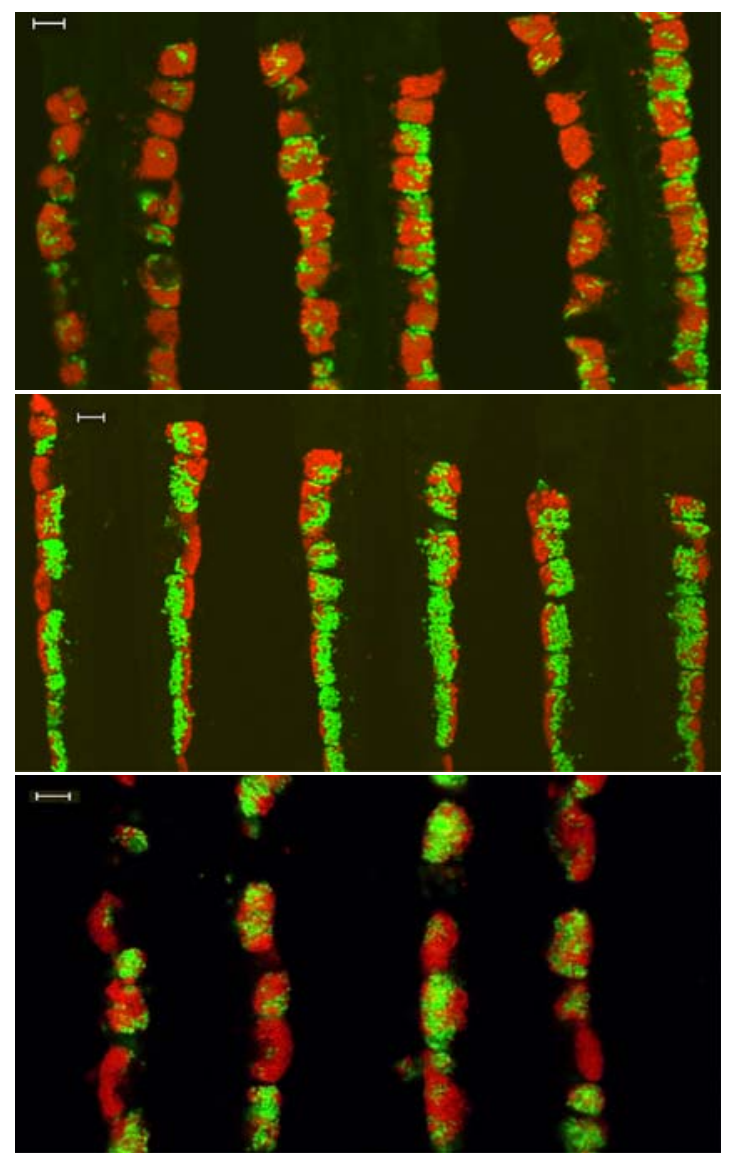

Fig. 3 A-C: Gill sections of Bathymodiolus specimens from the Mid-Atlantic Ridge hybridized with fluorescently-labeled probes specific to the methanotrophic symbiont (shown in green) and the thiotrophic symbiont (shown in red). Three (A and B) or 2 (C) gill filaments are shown, with a cross section of the descending and ascending lamellae of each filament visible. The ciliated end of each filament is oriented towards the top of each figure. Scale bars $=10 \mu \mathrm{m}$. A: B. azoricus from Lucky Strike. B: B. azoricus from Rainbow. C: B. puteoserpentis from Logatchev. 
Table 1: Shared nucleotide substitutions in the thiotrophic and methanotrophic 16S rRNA phylotypes in Bathymodiolus mussels from the Menez Gwen (MG), Lucky Strike (LS), Rainbow (RB), and Logatchev (LO) vent sites. The rare methanotrophrelated sequence found in only a single mussel from MG is not included in this table as it shows more than $3 \%$ sequence divergence to all other MAR methanotrophic symbiont sequences.

\begin{tabular}{|c|c|c|c|c|c|}
\hline \multirow[b]{2}{*}{ Thiotroph } & \multicolumn{3}{|c|}{ Nucleotide position ${ }^{a}$} & \multirow{2}{*}{$\begin{array}{l}\text { No. of sequences } \\
\text { (out of } 19 \text { total) }\end{array}$} & \multirow{2}{*}{$\begin{array}{c}\text { No. } \\
\text { of individuals }\end{array}$} \\
\hline & 1014 & 1015 & 1262 & & \\
\hline $\begin{array}{l}\text { Dominant phylotype } \\
\text { (MG, LS, RB, LO) }\end{array}$ & $\mathrm{T}$ & $\mathrm{T}$ & $\mathrm{C}$ & 18 & 10 \\
\hline Rare phylotype (RB) ${ }^{\mathrm{b}}$ & A & A & $\mathrm{T}$ & 1 & 1 \\
\hline
\end{tabular}

\begin{tabular}{|l|c|c|c|c|}
\hline Methanotroph & \multicolumn{2}{|c|}{$\begin{array}{c}\text { Nucleotide position } \\
\text { a }\end{array}$} & $\begin{array}{c}\text { No. of sequences } \\
\text { (out of } 17 \text { total) }\end{array}$ & $\begin{array}{c}\text { No. } \\
\text { of individuals }\end{array}$ \\
\hline $\begin{array}{l}\text { Dominant phylotype } \\
\text { (MG, LS, RB) }\end{array}$ & A & C & 5 & 5 \\
\hline $\begin{array}{l}\text { Dominant phylotype } \\
\text { LO) }\end{array}$ & G & C & 9 & 4 \\
\hline $\begin{array}{l}\text { Rare phylotype } \\
\text { LO) }\end{array}$ & A & T & 3 & 2 \\
\hline
\end{tabular}

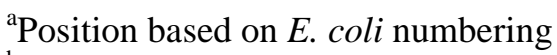

${ }^{\mathrm{b}}$ These 3 differences are shared with the rare thiotroph phylotype identified by Won et al. (2003) from a Rainbow mussel specimen (AY235676) 
Table 2: Sulfide and methane concentrations and ratios in end-member fluids from the Lucky Strike (LS), Rainbow (RB), Snake Pit (SP) and Logatchev (LO) vent sites, and distribution and relative abundance of thiotrophic (SOX) and methanotrophic (MOX) symbionts in the gill cells of mussels based on qualitative FISH observations from this study (LS, RB, LO) and Distel et al. 1995 (SP). Chemical data is from Douville et al. 2002 and Desbruyères et al. 2000.

\begin{tabular}{|l|l|c|c|c|c|c|}
\hline Site & Species & $\mathrm{H}_{2} \mathrm{~S}(\mathrm{mM})$ & $\mathrm{CH}_{4}(\mathrm{mM})$ & $\mathrm{H}_{2} \mathrm{~S} / \mathrm{CH}_{4}$ & Distribution & Relative abundance \\
\hline LS & \multirow{2}{*}{ B. azoricus } & $0.6-3.4$ & $0.5-1.0$ & $1.2-3.4$ & mixed & $\mathrm{SOX}>\mathrm{MOX}$ \\
\cline { 1 - 5 } RB & & $1.0-2.5$ & $2.2-2.5$ & $0.45-1.0$ & MOX basal & $\mathrm{SOX}<\mathrm{MOX}$ \\
\hline SP & \multirow{2}{*}{ B. puteoserpentis } & $2.7-6.1$ & $0.05-0.06$ & $54-102$ & mixed & $\mathrm{SOX}>\mathrm{MOX}$ \\
\cline { 1 - 5 } LO & & 0.8 & 2.1 & 0.38 & mixed & $\mathrm{SOX} \approx \mathrm{MOX}$ \\
\hline
\end{tabular}

